\title{
Sugammadex affects GH/GHR's signaling transduction on muscle cells by regulating the membrane-localized GHR level
}

\section{Sugammadex, membrana lokalize GHR seviyesini düzenleyerek kas hücreleri üzerindeki GH/GHR sinyal iletimini etkiler}

https://doi.org/10.1515/tjb-2021-0159

Received July 9, 2021; accepted November 15, 2021;

published online January 13, 2022

\section{Abstract}

Objectives: Sugammadex (also known as bridion) is a modified $y$-cyclodextrin, which is a reversal agent for the neuromuscular block. Growth hormone $(\mathrm{GH})$ has an important biological effect on muscle, regulating muscle growth and development. In the current work, we explored the effect of Sugammadex on GH's bioactivities.

Methods: Confocal laser scanning microscope (CLSM), flow cytometry, indirect immunofluorescence, Western-blot, and IP-WB were used to explore the effect of Sugammadex on GH's bioactivities.

Results: We found that Sugammadex reduced the activity of $\mathrm{GH}$ on muscle cells, which down-regulated $\mathrm{GH} /$ GHR-mediated intracellular signaling pathway, such as Janus kinase 2 (JAK2) and signal transducers and activators of transcription 5 (STAT5). We further study the potential biological mechanism by which Sugammadex downregulated GH/GHR-mediated signaling pathway, a series of related experiments were conducted, and found that

*Corresponding author: Jie Bai, UGS, Shanghai Children's Medical Center Affiliated to Medical College of Shanghai Jiaotong University, Shanghai, P. R. China, E-mail: baijie@scmc.cn.com.cn. https://orcid. org/0000-0002-0112-4940

Xiaoqian Lyu, Fei Xie and Yujuan Tao, Anesthesiology Department, Sanya Women and Children's Hospital Managed by Shanghai Children's Medical Center, Sanya City, P. R. China. https://orcid.org/ 0000-0002-8509-3562 (X. Lyu). https://orcid.org/0000-0002-22969790 (F. Xie). https://orcid.org/0000-0003-4177-8604 (Y. Tao)
Sugammadex may inhibit the proliferation of C2C12 cell via regulating the membrane-localized GHR, which may be the underlying mechanism by which Sugammadex suppressed GHR-induced signaling transduction. This work has laid the theoretical and experimental basis for further exploring the relationship between Sugammadex and GH's activity. Conclusions: In conclusion, this study laid a foundation for further study on the relationship between Sugammadex and GH's activity.

Keywords: cell proliferation; Janus kinase 2 (JAK2)-signal transducers and activators of transcription 5 (STAT5); muscle cells; Sugammadex.

\section{Öz}

Amaç: Sugammadeks (bridion olarak da bilinir), nöromüsküler bloğu tersine çeviren bir ajan olan modifiye bir $y$-siklodekstrindir. Büyüme hormonu $(\mathrm{GH})$, kas büyümesini ve gelişimini düzenleyebilen kas üzerinde önemli bir biyolojik etkiye sahiptir. Mevcut çalışmada, Sugammadex'in GH'nin biyoaktiviteleri üzerindeki etkisini araştırdık.

Gereç ve Yöntem: Sugammadex'in GH'nin biyoaktiviteleri üzerindeki etkisini araştırmak için Konfokal Lazer Tarama Mikroskobu (CLSM), Akış sitometrisi, dolaylı immünofloresan, Western-blot, IP-WB kullanıldı.

Bulgular: Sugammadex'in, Janus kinaz 2 (JAK2) ve sinyal transdüserleri ve transkripsiyon 5 aktivatörleri (STAT5) gibi GH/GHR aracılı hücre içi sinyal yolunu aşağı regüle eden bağırsak hücreleri üzerindeki GH aktivitesini azalttığını bulduk. Sugammadex'in GH/GHR aracılı sinyal yolunu aşağı regüle ettiği potansiyel biyolojik mekanizmayı daha fazla inceledik, bir dizi ilgili deney yapıldı ve Sugammadex’in 
membrana lokalize GHR'yi düzenleyerek $\mathrm{C} 2 \mathrm{C} 12$ hücresinin çoğalmasını engelleyebileceğini bulduk. Sugammadex'in GHR ile indüklenen sinyal iletimini baskıladığı temel mekanizma olabilir. Bu çalışma, Sugammadex ve GH aktivitesi arasındaki ilişkiyi daha fazla araştırmak için teorik ve deneysel temeli oluşturmuştur.

Sonuç: Sonuç olarak, bu çalışma, sugammadeks ve GH aktivitesi arasındaki ilişki üzerine daha fazla çalışma için bir temel oluşturdu.

Anahtar kelimeler: hücre çoğalmas1; JAK2-STAT5; Kashücreleri; Sugammadeks.

\section{Introduction}

Growth hormone (GH) is a peptide hormone secreted by the anterior pituitary gland, which is composed of 191 amino acids. It can promote the growth of bone, viscera and the whole body, promote protein synthesis, and affect the metabolism of fat and minerals [1]. In addition to the above functions, GH is also involved in regulating various physiological activities, such as gonadal maturation and metabolism [2]. Studies on mammals have shown that GH is also involved in immune regulation. At the tissue and cell level, the first step of GH is to bind to the growth hormone receptor (GHR) on the surface of target cell membrane, which mediates different signaling pathways and produces a series of physiological effects [3]. GHR is widely expressed in muscle, fat, breast, bone, kidney, embryonic stem cells, and immune cells. GH has two GHR binding sites, one is site 1 with high affinity, another is site 2 with weak affinity. After GH binds to GHR, a series of signal molecules are activated, such as signal transducer and activator of transcription (STATs), mitogenactivated protein kinase (MAPK), protein kinase C (PKC), and insulin receptor substrate (IRS) [4, 5].

Sugammadex (also known as bridion) is a modified $y$-cyclodextrin [6], which is a reversal agent for the neuromuscular block. In operation, muscle relaxant drugs can make the operation run smoothly $[7,8]$. But if the muscle relaxant remains in the body for a long time, which will lead to muscle fatigue and weakness. The use of Sugammadex can reverse the effect of the muscle relaxation, therefore Sugammadex could reduce the side effects of muscle relaxants [9-11].

GH has an important biological effect on muscle, such as promoting muscle cell proliferation. The use of Sugammadex reverses the effect of muscle relaxation [9-11]. Therefore, in this study, the effect of Sugammadex on the biological activity of GH is studied on the mouse cell line. We found that Sugammadex regulated GH-induced cell proliferation. We further studied the potential mechanism by which Sugammadex inhibited GH-induced cell proliferation, and the results showed that Sugammadex down-regulated Janus kinase 2 (JAK2)-signal transducers and activators of transcription 5 (STAT5) signaling induced by GH. Further study indicated that Sugammadex accelerates GH-induced GHR's down-regulation, this may be important reason for Sugammadex down-regulating GH's signaling. In conclusion, this study laid a foundation for further study on the relationship between Sugammadex and GH signaling.

\section{Materials and methods}

\section{Materials}

p-JAK2 (\#3771, 1:200 dilution), p-STAT5 (\#4322, 1:100 dilution) and p-AKT (\#4060, dilution) antibodies were purchased form Cell Signaling Technology (USA). Total STAT5 (\#94205, 1:300 dilution), STAT3 (\#9139, 1:200), AKT (\#9272, 1:100) antibodies were purchased from Cell Signaling Technology (USA). Dulbecco's Modified Eagle Medium (DMEM) and fetal bovine serum (FBS) were purchased from Thermo Fisher (USA). Polyvinylidene fluoride (PVDF) membrane was purchased from Millipore Biotech (MA, USA). Cell lysis buffer, BCA kit were purchased from Solarbio (China). Skim milk was purchased from Beyotime Biotechnology (China). GH was obtained from Sigma. Anti-GHR antibody was from Abcam. Horseradish peroxidase (HRP)-conjugated secondary antibodies sheep anti-mouse IgG and donkey anti-rabbit IgG antibody were obtained from cellular signaling technology (CST). Unless otherwise stated, other chemicals were obtained from Sigma-Aldrich (USA).

\section{Cell culture}

The mouse myoblast cell line $\mathrm{C} 2 \mathrm{C} 12$ was purchased from ATCC. $\mathrm{C} 2 \mathrm{C} 12$ was maintained in Dulbecco modified Eagle's medium (DMEM) containing $10 \% \mathrm{FBS}$ in a $37^{\circ} \mathrm{C}, 5 \% \mathrm{CO}_{2}$ cell incubator.

\section{Western-blot}

The $\mathrm{C} 2 \mathrm{C} 12$ cells were treated with $\mathrm{GH}$ alone or Sugammadex/GH mixture for the indicated time points. After washing, the cells were harvested with a cell scraper. After centrifugation, the supernatant was collected and boiled at $95{ }^{\circ} \mathrm{C}$ for $6 \mathrm{~min}$. The protein concentration was quantified by using a Pierce BCA protein assay kit (Pierce). From 25 to $50 \mu \mathrm{g}$ of samples were subjected to sodium dodecyl sulfate (SDS)-page and transferred to PVDF membrane. The membranes were washed and blocked for $1 \mathrm{~h}$ using 5\% BSA in Tris-buffered saline containing 0.1\% Tween 20. After three washes, the PVDF membranes were first incubated with the 
corresponding primary antibody (1:1,200 dilutions), and kept at $4{ }^{\circ} \mathrm{C}$ overnight. After washing the PVDF membranes for three times, a secondary antibody was added and incubated for $2 \mathrm{~h}$ at room temperature. After washing, Proteins on a membrane were checked using the ECL detection system.

\section{Confocal analysis}

$\mathrm{C} 2 \mathrm{C} 12 \mathrm{~s}$ were cultured in serum-free medium for $3 \mathrm{~h}$ the cells were then treated with GH or Sugammadex/GH mixture for indicated time points. After three washes, the cells were fixed, blocked and permeabilized with Trixon-100. After washing, the cells were first incubated with the corresponding primary antibody (1:1,200 dilutions), and kept at $4^{\circ} \mathrm{C}$ overnight. After washing three times, a secondary antibody was added and incubated for $2 \mathrm{~h}$ at room temperature. After washing, the cell samples were visualized with confocal laser scanning microscopy (CLSM, Olympus FV1000). Image analysis was performed using ImageJ software.

\section{Isolation of subcellular fractions}

Nuclear and cytosol fractions of the cells were isolated using nuclear/ Cytosol Fractionation Kit according to our manufacturer's protocol (BioVision Inc., Mountain View, CA, USA).

\section{Cell Proliferation Assay}

About $1 \times 10^{4}$ cells were seeded into a 96-well plate containing $100 \mu \mathrm{L}$ culture medium per well. The cells were then stimulated GH, Sugammadex or mixture of Sugammadex/GH at the indicated time points (24, 48, and $72 \mathrm{~h}$ ). Ten microliters CCK-8 solution (Dojindo, Kunamoto, Japan) was added into each well. After incubation for $2 \mathrm{~h}$, and absorbance at $450 \mathrm{~nm}$ was measured by a microplate reader (BioRad Lab).

\section{Analysis of apoptosis by propidium iodide staining}

The cells were stimulated with Sugammadex, after which single-cell suspensions were prepared by digestion, the cells were collected by centrifugation. Five hundred microliters of binding buffer were added to resuspend cell samples. After washing the cells for two times, the cell apoptosis was then detected by staining the cells with Annexin $\mathrm{V}$ and propidium iodide solution, followed by flow cytometry analysis.

\section{Analysis of cell cycle}

A total of $2 \times 10^{5} \mathrm{C} 2 \mathrm{C} 12$ cells per well were seeded into culture plate, followed by treatment of Sugammadex, GH or the mixture of Sugammadex/GH for 0.5-2 h. After washing, single-cell suspensions were prepared by digestion, the cells were collected by centrifugation. The cells were then fixed, and PI was added for staining for $0.5 \mathrm{~h}$ after washing, the cell samples were then analyzed by flow cytometry.

\section{Statistical analysis}

Statistical analysis was conducted using Graph Pad Prism software (version 8.0, Graph Pad Software, Inc). Data are expressed as the mean \pm SD One-way analysis of variance was used for comparison. A p-value $<0.05$ was considered statistically significant.

\section{Results}

\section{GHR expression on the $\mathrm{C} 2 \mathrm{C} 12$ cells}

GHR expression on C2C12 cells was analyzed by a confocal microscope, and the results indicated that GHR was expressed on the cell membrane of C2C12 cells (Supplementary Figure 1A). Then, colocalization analysis showed the interaction between GH and GHR on the $\mathrm{C} 2 \mathrm{C} 12$ cells (Supplementary Figure 1B).

\section{GHR-induced signaling profiles on the $\mathrm{C} 2 \mathrm{C} 12$ cells}

C2C12 cells were challenged with GH for different time points, and then the phosphorylation levels of GHR-mediated intracellular signaling molecules were analyzed by flow cytometry. Supplementary Figure 2 indicated that $\mathrm{GH}$ activates the GHR-mediated signaling pathway time-dependent. After 3 min of treatment with $100 \mathrm{ng} / \mathrm{mL} \mathrm{GH}$, JAK2-STAT5 activation was detectable, and maximal stimulation of JAK2-STAT5 signaling was demonstrated after $30 \mathrm{~min}$ of treatment with $100 \mathrm{ng} / \mathrm{mL}$ $\mathrm{GH}$ and declined after that time. In addition, we also detected the ERK1/2 activation. After 3 min of treatment with $100 \mathrm{ng} / \mathrm{mL} \mathrm{GH}$, ERK1/2 activation was detectable, and maximal activation of ERK1/2 signaling was found after $30 \mathrm{~min}$ of treatment with $100 \mathrm{ng} / \mathrm{mL} \mathrm{GH}$ and declined after that time.

\section{Sugammadex inhibited GH-mediated intracellular signaling}

The effect of Sugammadex on GH-mediated intracellular signaling were evaluated. Supplementary Figure 3 showed that Sugammadex significantly suppressed GH-induced intracellular signaling. Although Sugammadex significantly inhibited GH/GHR-mediated intracellular signaling, 
A

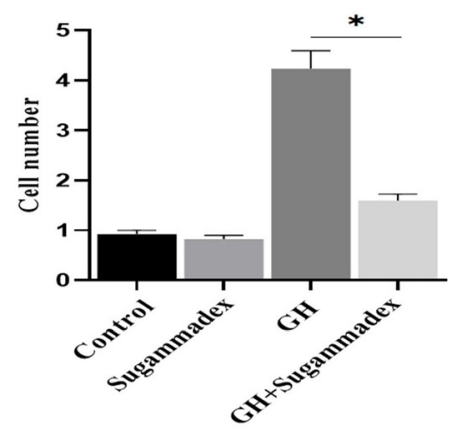

B
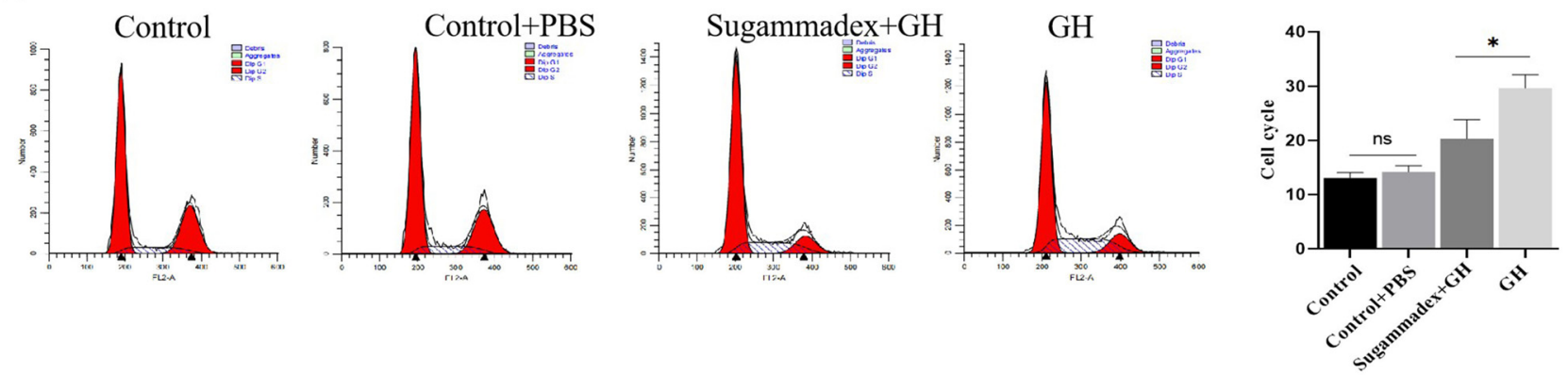

Figure 1: (A) Sugammadex inhibited GH's biological activity. Growth hormone (GH)-induced cell proliferation was significantly suppressed by Sugammadex treatment. (B) Sugammadex influences the cell cycle induced by GH. Data are represented as mean \pm standard deviation (SD). The asterisk indicates that the difference is statistically significant ( $p$-value $<0.05$ ).

and Sugammadex had no significant effect on the expression levels of non-phosphorylated JAK2, STAT5, and ERK1/2.

\section{Sugammadex suppressed GH-stimulated cell proliferation}

The effect of Sugammadex on GH-induced cell proliferation was evaluated. GH alone could significantly stimulate $\mathrm{C} 2 \mathrm{C} 12$ cell proliferation. However, the GH-induced cell proliferation was significantly suppressed by Sugammadex treatment, suggesting that Sugammadex could inhibit GH's biological activity (Figure 1A). Further experiments showed that Sugammadex has an influence on the cell cycle induced by GH (Figure 1B).

\section{Sugammadex suppressed GH-induced signaling pathway in vivo}

We further evaluated the effect of Sugammadex on GHR-mediated signaling in vivo. As shown in Figure 2A, there was no change in total GHR expression level after Sugammadex treatment. In addition, there was no significant difference in endogenous $\mathrm{GH}$ levels between the control group and Sugammadex treatment group (Figure 2B). Next, we analyzed the effect of Sugammadex on GH-induced signaling in vivo, we mainly observed JAK2-STAT5 signaling induced by GH in the muscle tissue, and it can be seen that GH-induced JAK2-STAT5 activation was significantly reduced compared to the control group (Figure 2C).

\section{The molecular mechanism by which Sugammadex inhibits GH/GHR signaling pathway}

To explore the molecular mechanism by which Sugammadex inhibited the GH/GHR-mediated signaling pathway, we first evaluated whether Sugammadex affected GH binding to GHR, and the results indicated that Sugammadex does not affect GH binding to GHR (Figure 3A). Furthermore, Sugammadex also did not inhibit GH's internalization (Figure 3B).

Next, we further explored the molecular mechanism by which Sugammadex suppressed GH-mediated signaling. We evaluated the effect of Sugammadex on membranelocalized GHR stability and found that the membranelocalized GHR was down-regulated by GH treatment in a time-dependent manner (Figure 3C). More interestingly, we found that GH-induced GHR down-regulation was accelerated by Sugammadex treatment (Figure 3C). Interestingly, Sugammadex alone has no effect on GHR 
A
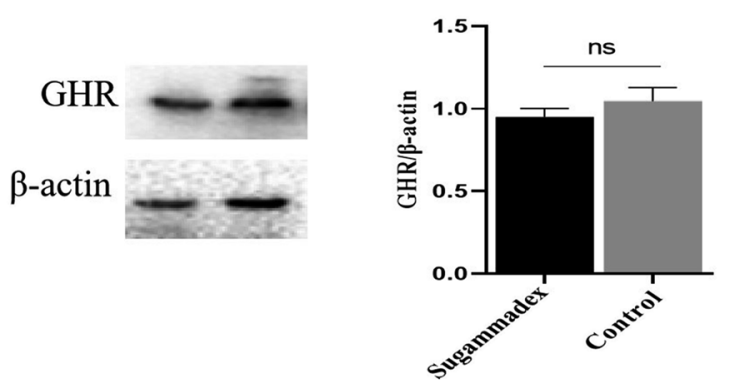

C

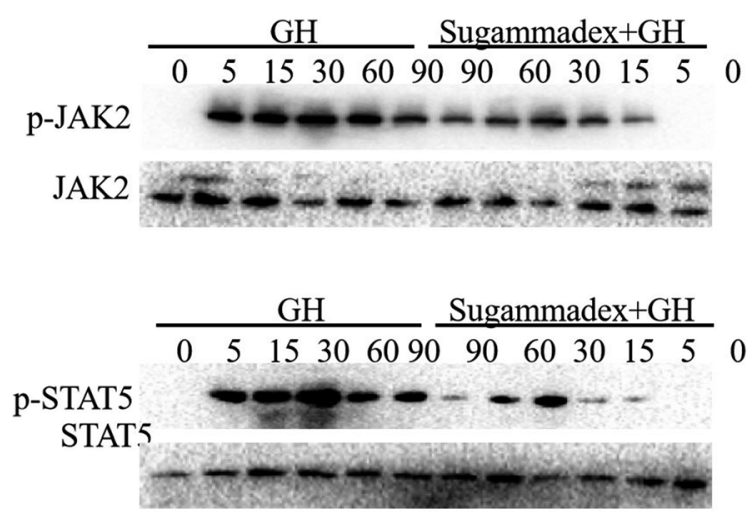

B

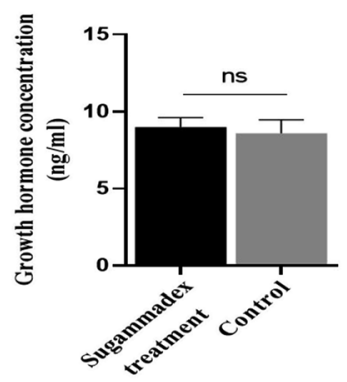

(Min)
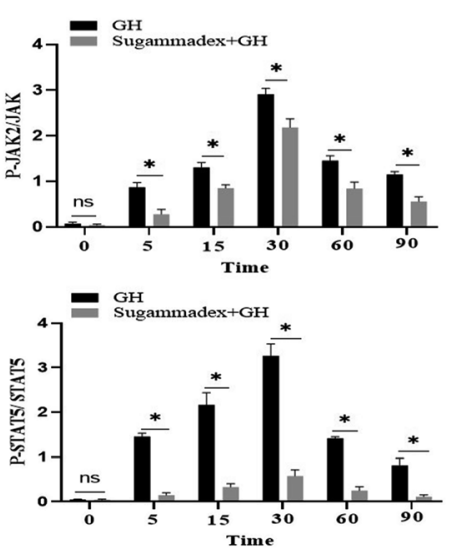

Figure 2: Sugammadex suppressed $\mathrm{GH}$-induced signaling.

(A) Sugammadex has no effect on growth hormone receptor (GHR) expression in vivo. (B) Endogenous growth hormone (GH) levels were assessed by ELISA assay. (C) Janus kinase 2 (JAK2)-signal transducers and activators of transcription 5 (STAT5) activation was significantly inhibited by Sugammadex treatment in vivo. Data are represented as mean \pm standard deviation (SD). The asterisk indicates that the difference is statistically significant ( $p$-value $<0.05$ ).

expression pattern by CLSM analysis (Figure 3D). This may be an important underlying mechanism for the GHR downregulation caused by Sugammadex treatment.

\section{Discussion}

GH is a single-chain polypeptide hormone, mainly secreted in the anterior pituitary, containing 191 amino acids with a molecular mass of $22 \mathrm{kDa}$ [12]. GH is a pivotal hormone which can regulate postnatal growth, and it regulates and metabolism of carbohydrates. GH displayed its biological roles by binding to GHR. GHR belongs to the class 1 cytokine receptor family [12]. GHR consists of three domains: an extracellular domain (ECD), a transmembrane domain (TMD), and an intracellular domain (ICD) [13]. GH/GHR exhibited its functions by activating JAK2-STAT5 signaling. Sugammadex is a modified $y$-cd (octakis-(6-deoxy-6-smercaptoproprionyl cd sodium salt)), it is a novel agent for the reversal of neuromuscular blockade [14]. It is well known that GH has the important bioactivities on muscle, Sugammadex reverses the effect of the muscle relaxation drugs. Therefore, in the current works, the effect of
Sugammadex on the biological activity of GH was evaluated on the mouse myoblast cell line $\mathrm{C} 2 \mathrm{C} 12$. We found that Sugammadex suppressed the GH-induced cell proliferation on the mouse myoblast cell line $\mathrm{C} 2 \mathrm{C} 12$. To our knowledge, this is the first report to study the effect of Sugammadex on GH activity.

GH displays its biological roles via GHR-mediated intracellular signaling. GH/GHR-mediated intracellular signaling includes STAT5/STAT3 AKT and ERK1/2, within which JAK2-STAT5 signaling is the most important signaling pathway [15]. In this work, we found that $\mathrm{GH}$ could activate GHR-mediated intracellular signaling, including JAK2-STAT5 signaling and ERK1/2 in a dosedependent manner. However, Sugammadex significantly down-regulated GHR-induced signaling pathway, Sugammadex had no significant effect on GH's secretion and GHR's expression. In addition, we also analyzed the GHR-mediated signaling pathway in muscle tissue in vivo and found that Sugammadex significantly down-regulated the GHR-induced signaling pathway in vivo.

However, when Sugammadex was used, the results indicated that Sugammadex could inhibit the proliferation of the mouse myoblast cell line $\mathrm{C} 2 \mathrm{C} 12$. However, using 
A
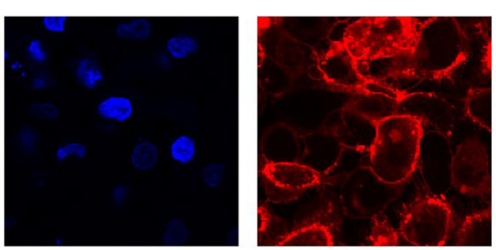

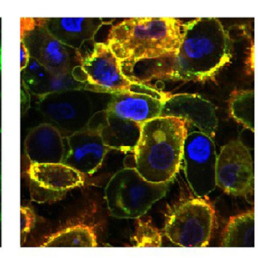

B

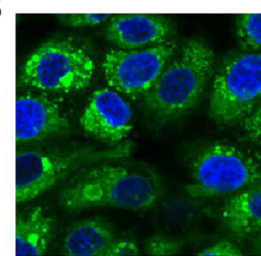

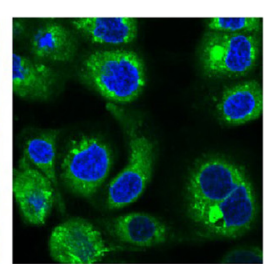

C
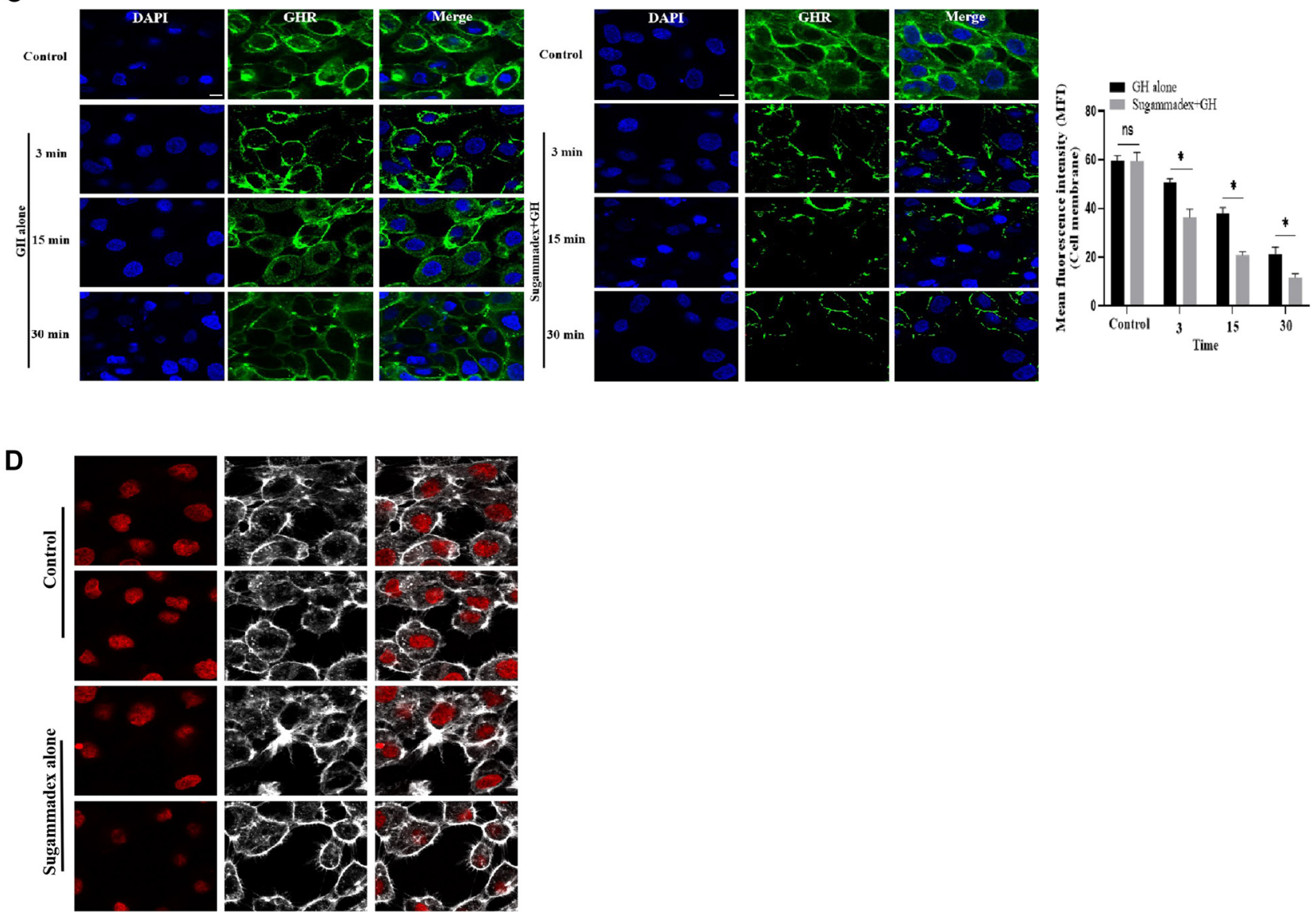

Figure 3: The molecular mechanism by which Sugammadex inhibits GH/GHR signaling pathway.

(A) Sugammadex does not affect growth hormone (GH) binding to growth hormone receptor (GHR). (B) Sugammadex does not inhibit GH's intracellular trafficking. (C) GHR was down-regulated by GH treatment. (D) GH-induced GHR down-regulation is accelerated by Sugammadex treatment. Sugammadex alone has no effect on GHR expression pattern by confocal laser scanning microscope (CLSM) analysis. Data are represented as mean \pm standard deviation (SD). The asterisk indicates that the difference is statistically significant ( $p$-value $<0.05)$.

Sugammadex alone does not affect $\mathrm{C} 2 \mathrm{C} 12$ cell proliferation. In addition, we also found that the cell cycle stage was affected by Sugammadex treatment.

We asked how Sugammadex down-regulated GHRmediated intracellular signaling pathway. To study the molecular mechanism by which Sugammadex inhibits GH/GHR signaling pathway, we first evaluated whether Sugammadex affected GH binding to GHR. The results indicated that Sugammadex does not affect GH binding to GHR. Further study showed that Sugammadex also did not inhibit GH's internalization.
Next, we further explored the molecular mechanism by which Sugammadex suppressed GH-mediated signaling from the perspective of GHR stability. The effect of Sugammadex on membrane-localized GHR stability was evaluated with or without GH treatment, and found that the GHR is down-regulated by GH stimulation in a time-dependent manner, it is well-known that the availability of GHR on cell membrane is one of the determinants for the ability of GHR -mediated signaling. The experimental results showed that GH-induced GHR downregulation (degradation) is accelerated by Sugammadex 
treatment. Interestingly, Sugammadex alone has no effect on GHR expression pattern by CLSM analysis, which may be an important underlying mechanism for the GHRmedicated signaling downregulation caused by Sugammadex treatment.

Studies have shown that the down-regulation of GH signaling is mainly via the suppressor of cytokine signaling (SOCS) proteins (such as SOCS1/2/3 and CIS) or protein phosphatase $[16,17]$. In addition, $\mathrm{GH}$ has shown a regulatory effect on 25-hydroxyvitamin $\mathrm{D}[18,19]$. In the current work, we found that there was no significant differences between Sugammadex-treated group and control group (data not shown). In addition, we further explored the expression of protein phosphatase, and no significant changes were detected between the treatment and control groups. This further indicates that the GHR-mediated signaling negative regulator is not involved in the downregulation of GHR signaling caused by Sugammadex treatment.

Taken together, in the current study, the effect of Sugammadex on the biological activity of GH is studied in vitro and in vivo. We found that Sugammadex could inhibit the GH-induced cell proliferation, which also suppressed GH's signaling pathway, and further experiments were carried out to explore the potential mechanism by which Sugammadex down-regulated JAK2-STAT5 signaling induced by $\mathrm{GH}$. We found that Sugammadex could accelerate GH-induced GHR's downregulation, this may be important reason for Sugammadex down-regulating GH's signaling. In conclusion, this study laid a foundation for further study on the relationship between Sugammadex and GH's activity.

Acknowledgments: Thank Professor Li for his help in the confocal observation experiment.

Research funding: This work is supported by Sanya maternal and child health hospital (20200809).

Author contributions: XiaoQian Lyu and Fei Xieperformed the experiments; Yujuan Tao drafted the manuscript. XiaoQian Lyu edited the manuscript. Yujuan Tao and XiaoQian Lyu conceived of the study, and participated in its design and coordination. All authors have accepted responsibility for the entire content of this manuscript and approved its submission.

Competing interests: The authors declare that they have no conflicts of interest.

Informed consent: Not applicable.

Ethical approval: All animal care and experimental procedures were approved by Sanya Maternity and Child Care Hospital.

\section{References}

1. Wren AM, Small CJ, Ward HL, Murphy KG, Dakin CL, Taheri S. The novel hypothalamic peptide ghrelin stimulates food intake and growth hormone secretion. Endocrinology 2000;141:4325-8.

2. Press M. Growth hormone and metabolism. Diabetes Metabol Res Rev 2010;4:391-414.

3. Gala RR. Prolactin and growth hormone in the regulation of the immune system. Proc Soc Exp Biol Med 1991;198:513-27.

4. Lanning NJ, Carter-Su C. Recent advances in growth hormone signaling. Rev Endocr Metab Disord 2006;7:225-35.

5. Fan Y, Menon RK, Cohen P, Hwang D, Clemens T, Digirolamo DJ. Liver-specific deletion of the growth hormone receptor reveals essential role of growth hormone signaling in hepatic lipid metabolism. J Biol Chem 2009;284:19937-44.

6. Adamus ML, Hrabálek L, Koutná J. Sugammadex (bridion) - our first experience with the reversal of moderate rocuroniuminduced neuromuscular block. Anesteziol a Intenzivní Medicína 2010;21:128-33.

7. Yang LP, Keam SJ. Sugammadex: a review of its use. Drugs 2009; 69:919-42.

8. Insinga R, Maiese EM, Devine S. Hospital budget impact of Sugammadex (bridion) for reversal of neuromuscular blockade. Value Health 2015;18:A281.

9. Shah M. Neuromuscular blocking agents and skeletal muscle relaxants. Side Eff Drugs Annul 2018;40:183-91.

10. Meistelman C, Donati F. Do we really need Sugammadex as an antagonist of muscle relaxants in anesthesia? Curr Opin Anaesthesiol 2016;29:462-7.

11. Igout A, Van Beeumen J, Frankenne F, Scippo ML, Devreese B, Hennen G. Purification and biochemical characterization of recombinant human placental growth hormone produced in Escherichia coli. Biochem J 1993;295:719-24.

12. Moutoussamy S, Kelly PA, Finidori J. Growth-hormone-receptor and cytokine-receptor-family signaling. FEBS J 2010;255:1-11.

13. Postel-Vinay MC, Finidori J. Growth hormone receptor: structure and signal transduction. Ann Endocrinol 1995;133:209-12.

14. Suzuki T. Sugammadex (org 25969 , modified $\gamma$-cyclodextrin). Masui Jpn J Anesthesiol 2006;55:834-40.

15. Ji S, Frank SJ, Messina JL. Growth hormone-induced differential desensitization of stat5, erk, and akt phosphorylation. J Biol Chem 2002;277:28384-93.

16. Ram PA, Waxman DJ. Socs/cis protein inhibition of growth hormone-stimulated stat5 signaling by multiple mechanisms. J Biol Chem 1999;274:35553.

17. Ram PA, Waxman DJ. Role of the cytokine-inducible sh2 protein cis in desensitization of stat $5 \mathrm{~b}$ signaling by continuous growth hormone. J Biol Chem 2001;275:39487-96.

18. Vurgun E, Memet B, Kocaturk E, Guntas G. Evaluation of serum 25-hydroxyvitamin D levels and cortisol/dehydroepiandrosterone sulfate ratio in chronic spontaneous urticaria. Turk J Biochem 2021;46:191-6.

19. Şahin K, Elevli M, Avcı R, Coskun C, Kiremitçi YS, Koldaş M. Determination of vitamin 25-hydroxyvitamin D deficiency and insufficiency cut-off values in children. Turk J Biochem 2021;46:183-9.

Supplementary Material: The online version of this article offers supplementary material (https://doi.org/10.1515/tjb-2021-0159). 